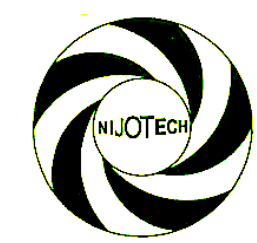

Nigerian Journal of Technology (NIJOTECH)

Vol. 39, No. 1, January 2020, pp. $306-\mathbf{3 1 4}$

Copyright@ Faculty of Engineering, University of Nigeria, Nsukka

Print ISSN: 0331-8443, Electronic ISSN: 2467-8821

www.nijotech.com

http://dx.doi.org/10.4314/njt.v39i1.34

\title{
ESTIMATION AND COMPARISON OF REFERENCE EVAPOTRANSPIRATION WITHIN KADUNA CENTRAL DISTRICT, NIGERIA, USING FOUR DIFFERENT METHODS
}

\author{
N. E. Onwuegbunam ${ }^{1}$, D. O. Onwuegbunam ${ }^{2}$ and A. Dare ${ }^{3, *}$ \\ 1, DEPARTMENT OF BASIC SCIENCE AND GENERAL StUdies, ForeSTRY RESEARCH INSTITUTE OF NigERIA, FEDERAL \\ College of Forestry MeChanization, Afaka, Kaduna, Kaduna State, NIGERIA \\ 2, 3, Department of Agricultural \& Bio-Environmental Engineering, Federal College of Forestry \\ MeCHANizATION, AFAKA, KADUNA, NIGERIA \\ E-mail addresses: 1 esoheanddona@gmail.com, 2 donancy2001@yahoo.com, \\ 3 akinrinsholadare@yahoo.com
}

\begin{abstract}
The reference evapotranspiration (ETo) within Kaduna Central District, Nigeria was estimated from a 30-year climatological data using four different methods namely, Penman-Monteith (PM), Blaney Criddle (BC), Hargreaves (HGRV) and Piche evaporimeter (PiEv) (atmometer) methods. The study shows that the highest ETo values obtained from PM, BC and PiEv were $6.43 \mathrm{~mm} /$ day, $7.58 \mathrm{~mm} /$ day and $8.63 \mathrm{~mm} /$ day, respectively, and these occurred in February, except for HGRV which estimated its highest ETo (3.73 mm/day) in March. The lowest ETo values were obtained in August for all the methods. By means of the confidence index (c), agreement or concordance index (d) and correlation coefficients (r) statistics the BC, HGRV and PiEV ETo values were correlated with that of $P M$, as the standard. Results showed that BC, HGRV and PiEv gave c-values of $0.88,0.48$ and 0.67 , respectively. Hence, BC-PM, HGRV-PM and PiEv-PM correlations were adjudged as excellent, bad and good, respectively, on the basis of criteria for interpretation of the performance of methods of ETo estimations. Blaney-Criddle reference evapotranspiration method gave the best estimate in comparison to the Penman-Monteith standard in the study area. Hence, the Blaney-Criddle ETo can be calibrated with the Penman-Monteith ETo and used effectively within the Kaduna Central District conditions for irrigation water management decisions.
\end{abstract}

Keywords: Estimation and comparison, Reference evapotranspiration, Methods, Kaduna Central District, Nigeria.

\section{INTRODUCTION}

In agriculture, evapotranspiration (ET) refers to crop water use. The ET process is a key variable in irrigation management, crop growth, hydrologic cycle, plant physiology, soil-plant-water-atmosphere relationships, microclimate and surface interactions, and drainage studies [1]. In a world of competing water demands amidst global climate change, it is important to maximize the efficiency of water usage and one of the ways to do this is by determining the evapotranspiration needs of specific locations so as to ascertain the proportion allocated to irrigated agriculture.

While ET is broadly defined as the combination of the processes of both evaporation from soil and plant surfaces and transpiration from plant canopies through the stomata to the atmosphere, reference evapotranspiration $\left(E T_{0}\right)$ is defined as the rate of evapotranspiration from a hypothetical reference crop with an assumed crop height of $0.12 \mathrm{~m}$, a fixed surface resistance of $70 \mathrm{~s} / \mathrm{m}$ and an albedo of 0.23 , closely resembling the evapotranspiration from an extensive surface of green grass of uniform height,

* Corresponding author, tel: +234 8023786572 
actively growing, well-watered, and completely shading the ground [2]. ETo provides a standard to which ET at different periods of the year or in other regions can be compared and ET of crops can be related [2]. ETo is a concept to measure the evaporative demand of the atmosphere, independent of the crop type, crop development and management practices [3]. Evapotranspiration is a significant variable for meteorological and hydrological research and also for agrarian water reservoirs organization [4].

$\mathrm{ET}_{0}$ evaluation involves either direct measurement with atmometer (piche evaporimeter) or evaporation pans, while indirectly, it can be evaluated by means of analytical or empirical methods such as the FAO Penman Monteith (PM), Blaney Criddle (BC), Hargreaves (HGRV), Thornthwaite (TW), Jensen and Haise (JHSE), etc. The readings taken with atmometers and evaporation pans are normally converted from evaporation to evapotranspiration using appropriate factors. The empirical methods use recorded climatic parameters to estimate the ET. Studies have shown that many models are site and location specific; others reduce the input variables to make for adaptability, peculiarity or cost reduction of input gathering [5].

In this study, the $\mathrm{ET}_{0}$ values computed by $\mathrm{PM}, \mathrm{BC}$ and HGRV empirical methods, as well as that computed from recorded evaporation measurements with atmometer are being evaluated. The International Scientific Society has considered the PM empirical model as the best because it gives accurate results when compared with other methods in several locations of the globe [2]; it has been considered to be the standard method that can be used anywhere without the necessity to calibrate [6], [7]. This model, however, requires the largest number of climatic data. The necessity of comparison, sensitivity testing and calibration methods in a local context is emphasized by a large number of studies and a local test appears indispensable as a means of means of finding the most suitable model for an area [7]. Large investment in irrigation projects development in any area needs sound estimates of crop water demands against risk of crop failure due to drought [5]. These estimates are obtainable from various evapotranspiration models.

The challenge with using the Penman-Monteith method, however, is that it requires many climatic variables for its determination and this has often made it difficult to use in areas without the needed data. On the other hand, the Blaney Criddle and Hargreaves methods require a single climatic variable - temperature or solar radiation $[8,9]$.

Generally, Kaduna State, including the study area, is known for dry season horticultural crops production through irrigation. Crops usually grown in the area through irrigation are cabbage, carrots, tomatoes, maize, pepper, cucumber and onions [10]. The irrigation schemes are mostly in small and medium scale and [11] has shown that irrigated crop production in the area is profitable. To boost irrigation in Kaduna State several earthdams and dams have been constructed such as the Kufana, Sabon Sarki, Likarbu, Zuntu, Fatika, Matari and Pambeguwa earthdams. Others are Kangim, Gimbawa, Bagoma, Shika, Kubani, Gurara, Galma and Hunkuyi dams [12]. Often, the water extracted from dams and rivers for irrigation is in competing demand with other uses such as municipal water supply and industrial uses. So there is need for right estimations and allocation for the several uses.

A major challenge to irrigation scheduling using climatological approach is the availability of the required climatic data needed to estimate the water use. The results of this study, will offer irrigation planners and users within the study area the simple estimation method of highest efficiency and requiring fewer variables. Based on this justification, the study objective is to estimate the reference evapotranspiration within Kaduna Central District, Nigeria, comparing four different estimation methods and recommending the model with the best correlation with FAO-PM model.

\section{METHODOLOGY}

\subsection{Description of the Study Area}

Kaduna Central District comprises Igabi, Kaduna North, Kaduna South, Chikun, Giwa, Birnin Gwari and Kajuru Local Government Areas, and stretches over latitude $10.32^{\circ} \mathrm{N}-10.66^{\circ} \mathrm{N}$ and longitude $6.54^{\circ} \mathrm{E}-$ $7.68^{\circ} \mathrm{E}$. The map of Kaduna State indicating weather stations, including the study area is shown in Figure 1 [13]. Generally, the climate of the study area is characterized by a clear distinction between dry and rainy seasons. The rainy season lasts from mid-April to early October. Kaduna has an annual mean rainfall of 1200 [14]. The temperature range (Figure (2a) is $28^{\circ} \mathrm{C}$ to $36^{\circ} \mathrm{C}$ for the maximum scale and $15^{\circ} \mathrm{C}$ to $23^{\circ} \mathrm{C}$ for the minimum scale [15], [16]. The humidity range (Figure $2 \mathrm{~b}$ ) is $24 \%$ to $83 \%$, with the lowest and highest values occuring in February and August, 
respectively [15], [16]. Harmattan is at its peak between December and February and the relative humidity is very low. Thereafter, the weather is hot in March and April, with March recording the highest mean temperature of $36^{\circ} \mathrm{C}$ [15]. The wind speed and sunshine hour data for the District are presented in Figures $2 \mathrm{c}$ and $2 \mathrm{~d}[15,16]$.

Kaduna is classified under the Isoberlinia or Northern Guinea Savannah vegetation characterized generally by woodland consisting of different layers rather less distinct than those of the forest [17]

\subsection{ETo Computation Methods}

The methodology for ETo computation or measurement are as presented as follows.

\subsubsection{The FAO Penman-Monteith method}

This is most commonly used empirical approach to $\mathrm{ET}_{0}$ estimation [18]. The method gives an equation which is a close, simple representation of the physical and physiological factors governing the evapotranspiration process. It was expressed by [2] as:

$$
E T_{o}=\frac{0.408 \Delta\left(R_{n}-G\right)+\gamma_{T+273} \frac{900}{T+2}\left(e_{S}-e_{a}\right)}{\Delta+\gamma\left(1+0.34 U_{2}\right)}
$$

where, $E T_{0}$ is the estimated reference evapotranspiration $\left[\mathrm{mm} \mathrm{day}{ }^{-1}\right], R_{n}=$ the surface radiation balance $\left[\mathrm{MJ} \mathrm{m}^{-2}\right.$ day $\left.^{-1}\right], \mathrm{G}=$ sensible heat

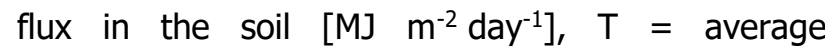
atmospheric temperature $\left[{ }^{\circ} \mathrm{C}\right], \mathrm{u}_{2}=$ wind speed at 2 $\mathrm{m}$ height $\left[\mathrm{m} \mathrm{s}^{-1}\right], \mathrm{e}_{\mathrm{s}}=$ saturation vapour pressure $[\mathrm{kPa}], \mathrm{e}_{\mathrm{a}}=$ actual vapour pressure $[\mathrm{kPa}], \Delta=$ slope of the water vapour saturation pressure curve $\left[\mathrm{kPa}{ }^{\circ} \mathrm{C}^{-}\right.$ $\left.{ }^{1}\right]$ and $\mathrm{y}=$ psychrometric constant $\left[\mathrm{kPa}{ }^{\circ} \mathrm{C}^{-1}\right]$.

The above equation was computed with the CROPWAT 8.0 software, with the input parameters as maximum temperature $\left({ }^{\circ} \mathrm{C}\right)$, minimum temperature $\left({ }^{\circ} \mathrm{C}\right)$, humidity $(\%)$, sunshine hour, and wind speed (Km/day).

\subsubsection{Blaney Criddle method}

The Blaney Criddle method for ETo estimation is simple [18], being based on average temperature as the only required climatic parameter. The equation is given as:

$$
E T_{o}=p\left(0.46 T_{\text {mean }}+8\right)
$$

where, $\mathrm{ET}_{0}$ is reference crop evapotranspiration ( $\mathrm{mm} /$ day) as an average for a period of 1 month, $T_{\text {mean }}$ is mean daily temperature $\left({ }^{\circ} \mathrm{C}\right)$ and $\mathrm{p}$ is Mean daily percentage of annual daytime hours.

\subsubsection{Hargreaves method}

Hargreaves method, like the Blaney Criddle approach, uses temperature data to determine $\mathrm{ET}_{0}$, especially in areas where many meteorological data are unavailable [19]. [20], [21] claimed that the ET。 equation given by Hargreaves is simple, reliable, and recommended it for worldwide use in irrigation scheduling. The Hargreaves equation for $\mathrm{ET}_{\mathrm{o}}$ is given by [21] as:

$E T_{o}=0.0023 R_{a}\left(T_{\max }-T_{\min }\right)^{0.5}\left(\frac{T_{\max }+T_{\min }}{2}+17.8\right)(3)$ where, $E T_{0}$ is the reference evapotranspiration (mm/day), $R_{a}$ is the extra-terrestrial solar radiation $\left(\mathrm{MJ} \mathrm{m}^{-2} \mathrm{~d}^{-1}\right), \mathrm{T}_{\max }$ is maximum air temperature $\left({ }^{\circ} \mathrm{C}\right)$ and $T_{\min }$ is minimum air temperature $\left(T_{\min }\right)$.

\subsubsection{Piche evaporimeter (atmometer)}

Existing evaporation data from piche evaporimeter measurements in the study area were converted to reference evapotranspiration [22], [23] by the equation:

$$
E T_{o}=a E_{p i p}(\sigma)
$$

where,

$a=a$ factor that considers the semi-protection of the piche evaporimeter from the solar radiation (= 0.27)

$\mathrm{E}_{\mathrm{pi}}=$ the evaporation reading by piche evaporimeter ( $\mathrm{mm} /$ day)

$\rho(\sigma)=$ a prevailing temperature dependent factor $(=2.41)$

\subsection{Data Analysis}

The ETo results estimated from the different methods were subjected to statistical regression analyses, considering the linear model. The analysis of the results was done by means of the following methods: the agreement or concordance index (d) as expressed in Equation (5) [7], [24], [25]; the confidence or performance index (c) stated as Equation (6) [26]; and the coefficient of correlation (r) and determination $\left(r^{2}\right)$.

$$
d=1-\left[\frac{\sum_{\mathrm{i}=1}^{\mathrm{N}}\left(\mathrm{P}_{\mathrm{i}}-\mathrm{O}_{\mathrm{i}}\right)^{2}}{\sum_{\mathrm{i}=1}^{\mathrm{N}}\left(\left|\mathrm{P}_{\mathrm{i}}-\overline{\mathrm{O}}\right|+\mid \mathrm{O}_{\mathrm{i}}-\overline{\mathrm{O}}\right)^{2}}\right]
$$

where, $d$ is the agreement or concordance index, $P_{i}$ is the predicted $\mathrm{ET}$ o by BC, HGRV and PEv methods, $\mathrm{O}_{i}$ is the $\mathrm{ET}_{0}$ value computed by the PM equation and $\overline{0}$ is the mean of the observed values.

$$
c=r . d
$$

where, $c$ is the confidence or performance index and $d$ is the Willmott's agreement or concordance index. 
The criteria for interpreting the performance of the $\mathrm{ET}_{\mathrm{o}}$ estimation methods are presented in Table 1.

\section{RESULTS AND DISCUSSION}

The reference evapotranspiration values from the various methods (Figure 3 ) showed a similar trend for each of the months under investigation. $E T_{0}$ increased from January to March, then decreased progressively from March to August and rises again till it peaks in February and March. The piche evaporimeter method produced the highest ETo values from January to April, and then November to December. This was followed by the PenmanMonteith method, Blaney Criddle and Hargreaves, respectively.

ETo for Kaduna are not readily available but a study carried out by [3] for Kano, Nigeria, in the same region as Kaduna but a distance of $202 \mathrm{~km}$ away showed that Kano has its highest ETo value of 12.5 $\mathrm{mm} /$ day, recorded in February, and the lowest value of $6.04 \mathrm{~mm} /$ day in August. These values are largely at variance with that of Kaduna, which measured $8.63 \mathrm{~mm} /$ day and $1.67 \mathrm{~mm} /$ day, under piche evaporimeter method, for the maximum and minimum values, respectively. A common trend in the results from both cities is that the highest ET。 occurred in February while the lowest occurred in August. Based [3], Kano is known to have higher mean temperatures than Kaduna, and also lower relative humidity. For this reason the $\mathrm{ET}_{0}$ of Kaduna is expected to be lower because $\mathrm{ET}_{0}$ decreases with decrease in temperature and increase in humidity. $A$ similar ETo results of Zaria, Nigeria, $67 \mathrm{~km}$ away from Kaduna (within the same state and ecological zone), obtained by [27] and [28], during its 2008/2009 and $2009 / 2010$ irrigation seasons showed that the highest ETo $(6.70 \mathrm{~mm} /$ day, $6.90 \mathrm{~mm} /$ day $)$ occurred in February and March, respectively. These results are similar to that of Kaduna $(6.23 \mathrm{~mm} /$ day and 6.43 $\mathrm{mm} /$ day) in February and March, respectively, using the Penman-Monteith method. The slightly higher values for the $\mathrm{ET}_{0}$ of Zaria were traced to the effects of higher wind speed for Zaria (229.3 km/day, 183.0 $\mathrm{km} /$ day) during these periods than for Kaduna (181.5 $\mathrm{km} /$ day, $165.0 \mathrm{~km} /$ day). Also, the sunshine hour durations for Zaria in the two seasons (9.6 hr, $9.0 \mathrm{hr}$ ) were higher than those of Kaduna ( $9.3 \mathrm{hr}, 8.6 \mathrm{hr}$ ). An analysis of variance of the ETo values among the different ETo estimation methods showed that there was significant difference in the ETo values among them $\left(F_{\text {calc. }}=4.2278, F_{\text {crit. }}=2.0666, p\right.$-value $=$ 0.000482). By implication, therefore, the ETo values from the models are not statistically similar and each has to be evaluated for test of efficiency in the study area.

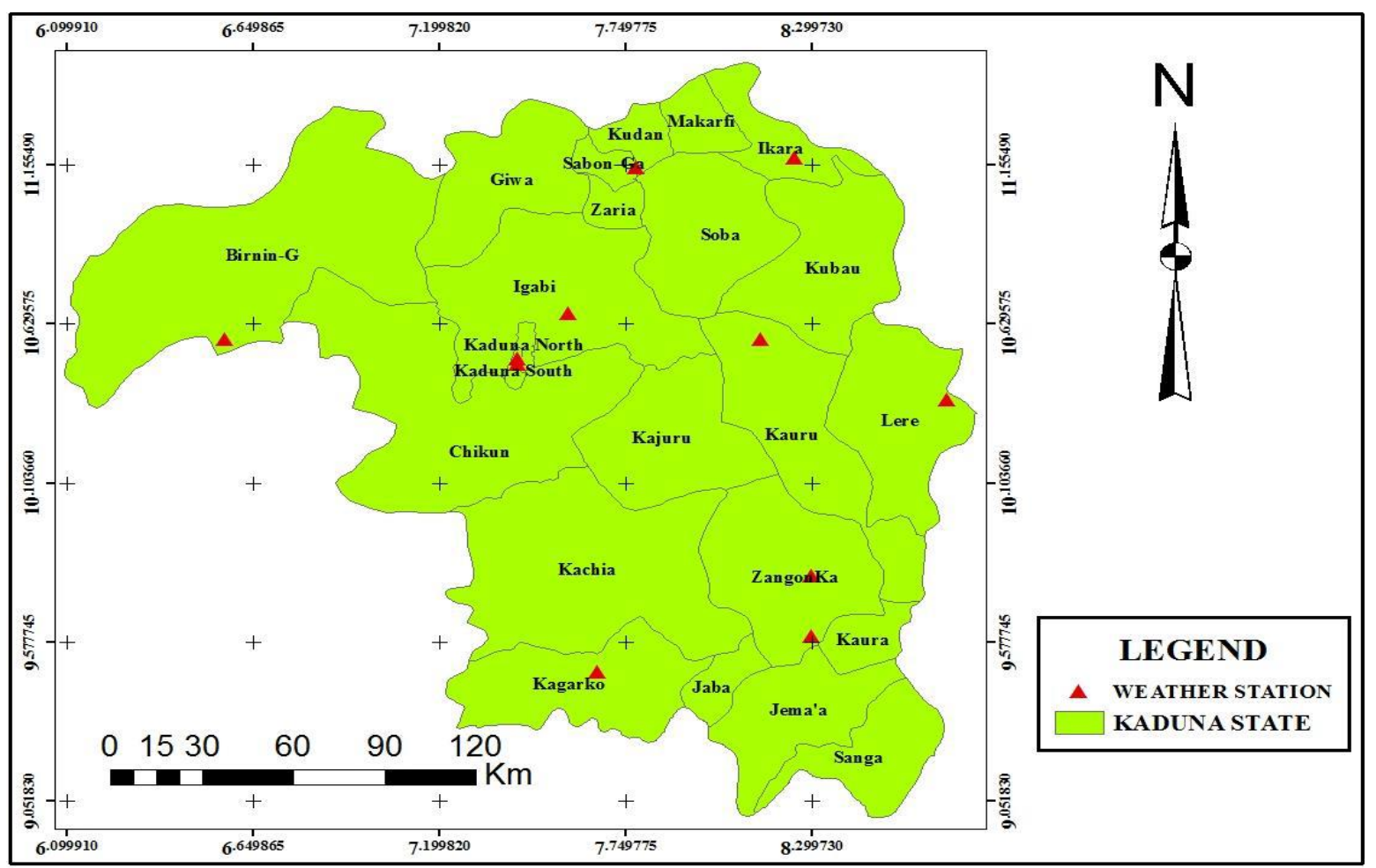

Fig. 1: Map of Kaduna showing weather stations including Kaduna North, Igabi and Kaduna South [13] 


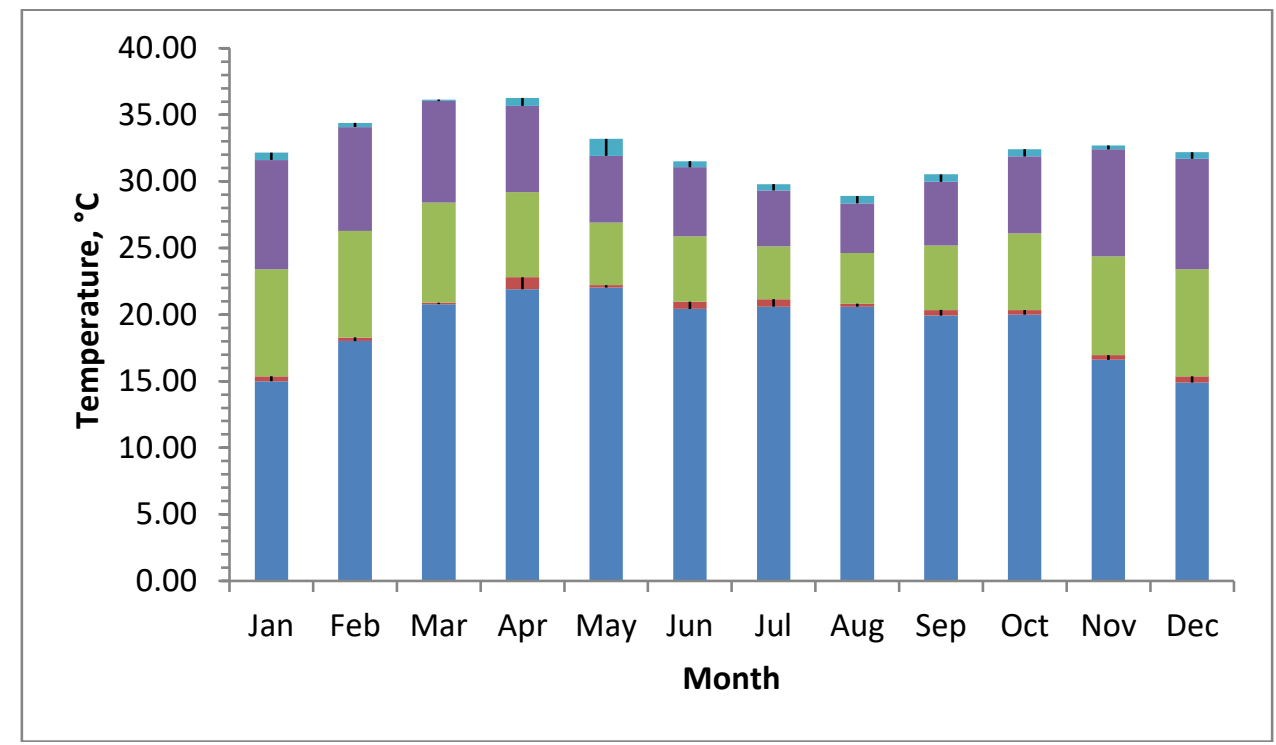

Fig2a: Mean monthly temperatures within Kaduna Central District, Nigeria

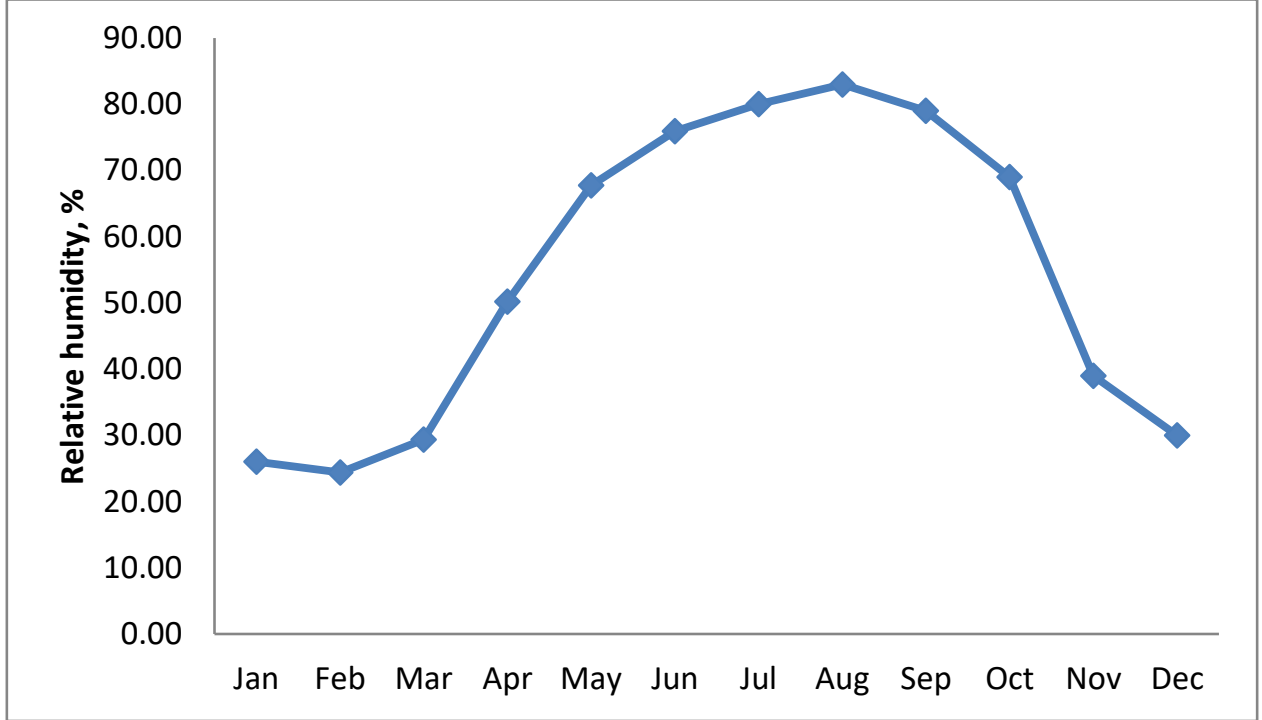

Fig. 2b: Mean monthly relative humidity within Kaduna Central District, Nigeria

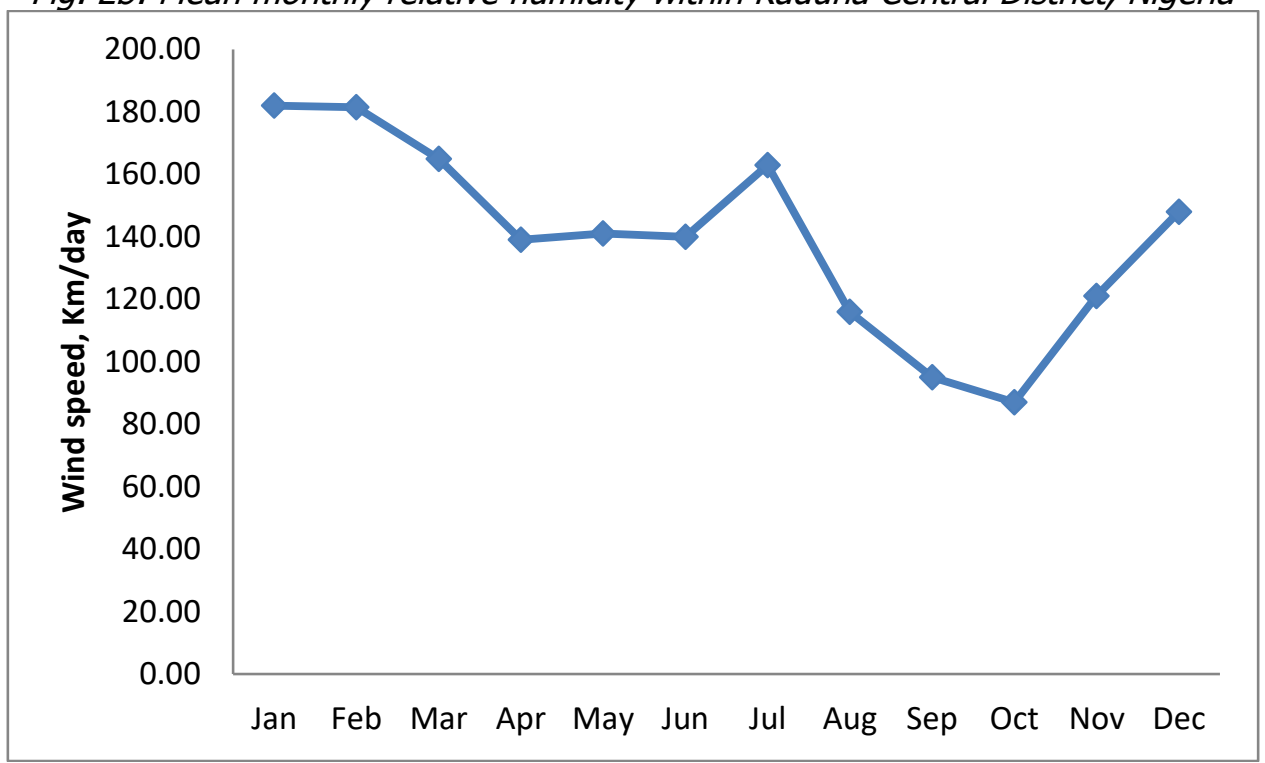

Fig. 2c: Mean monthly wind speed within Kaduna Central District, Nigeria 


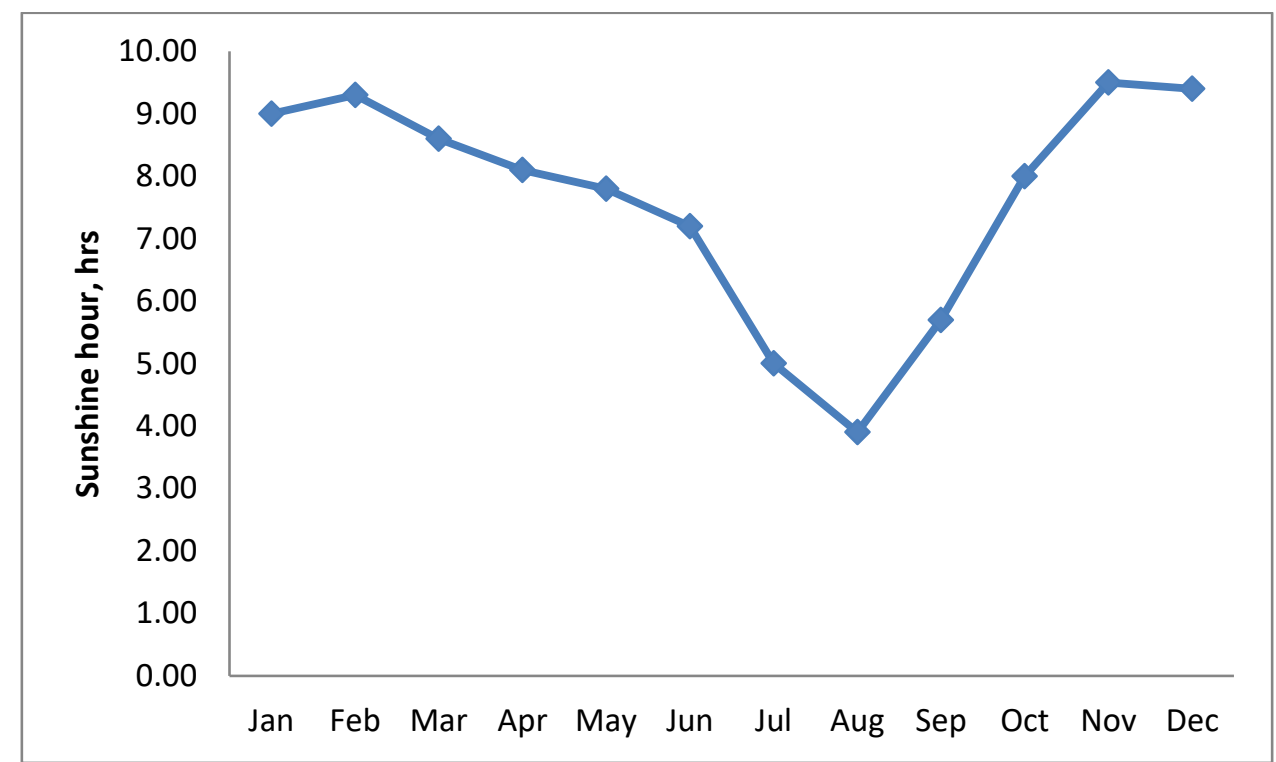

Figure 2d: Mean sunshine hour within Kaduna Central District (1986-2015)

Table 1: Criteria for interpreting different ETo estimation methods by the confidence index, $c$ and correlation Confidence index, $\mathrm{c}$ coefficient, $r$

\begin{tabular}{ll}
\hline$>0.85$ & Excellent \\
$0.76-0.85$ & Very good \\
$0.66-0.75$ & Good \\
$0.61-0.65$ & Median \\
$0.51-0.60$ & Affordable \\
$0.41-0.50$ & Bad \\
$<0.4$ & Terrible \\
\hline Correlation coefficient, $r$ & Precision \\
\hline $0.9-1.0$ & Almost perfect \\
$0.7-0.9$ & Very high \\
$0.5-0.7$ & High \\
$0.3-0.5$ & Moderate \\
$0.1-0.3$ & Low \\
\hline
\end{tabular}

Source: Camargo and Sentelhas [25]

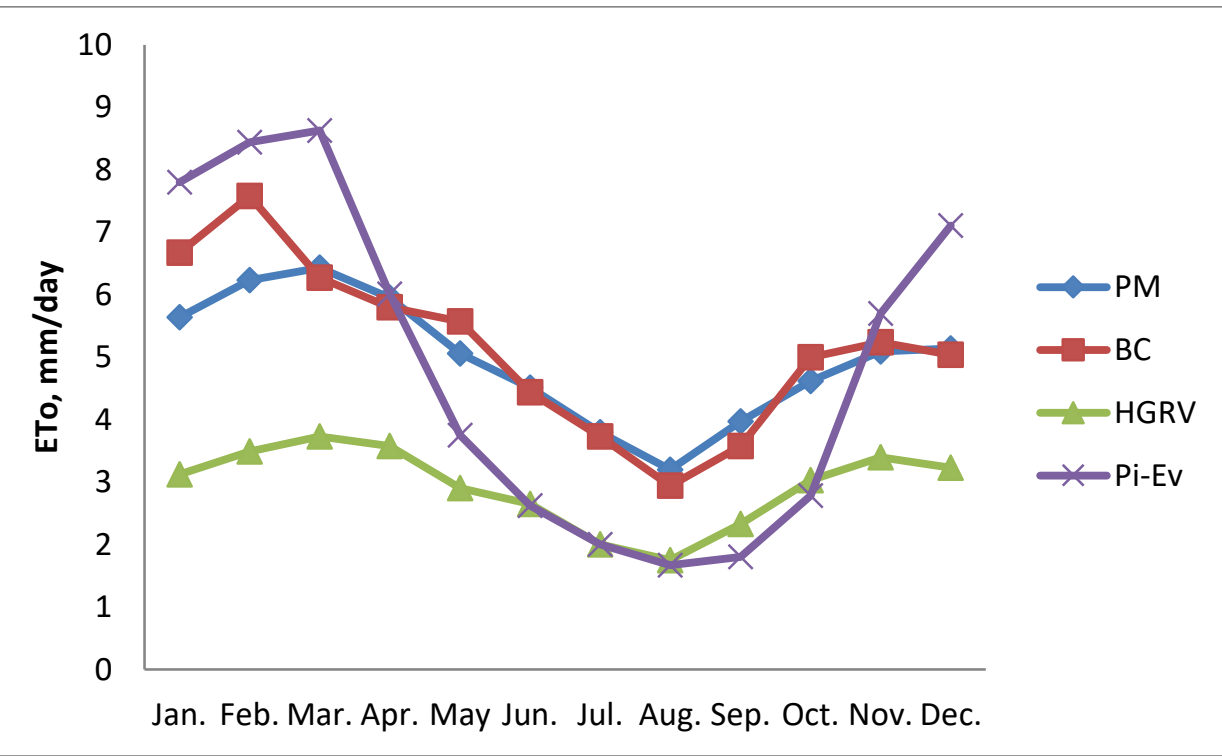

Fig. 3: Computed ETo based on PM, BC, HGRV and PiEv methods 


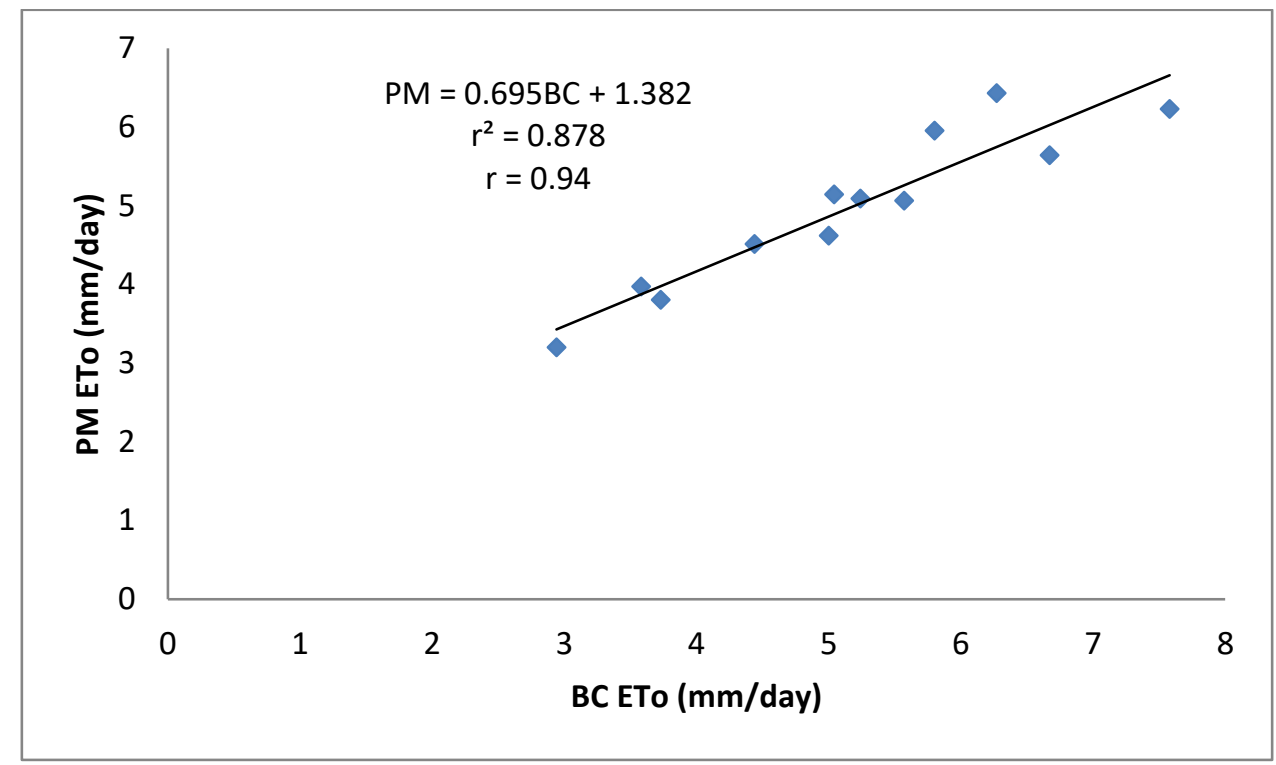

Fig. 4: Correlation between estimated $E T_{o}$ by PM and BC

Table 2: Concordance (d), correlation ( $r$ ) and confidence (c) test values for the different methods with respect to Penman-Monteith method within Kaduna Central District

\begin{tabular}{llll}
\hline Methods & $\mathrm{r}$ & $\mathrm{d}$ & $\mathrm{c}$ \\
\hline PM $\times$ BC & 0.94 & 0.94 & 0.88 \\
PM $\times$ HGRV & 0.95 & 0.51 & 0.48 \\
PM $\times$ PiEv & 0.91 & 0.74 & 0.67 \\
\hline
\end{tabular}

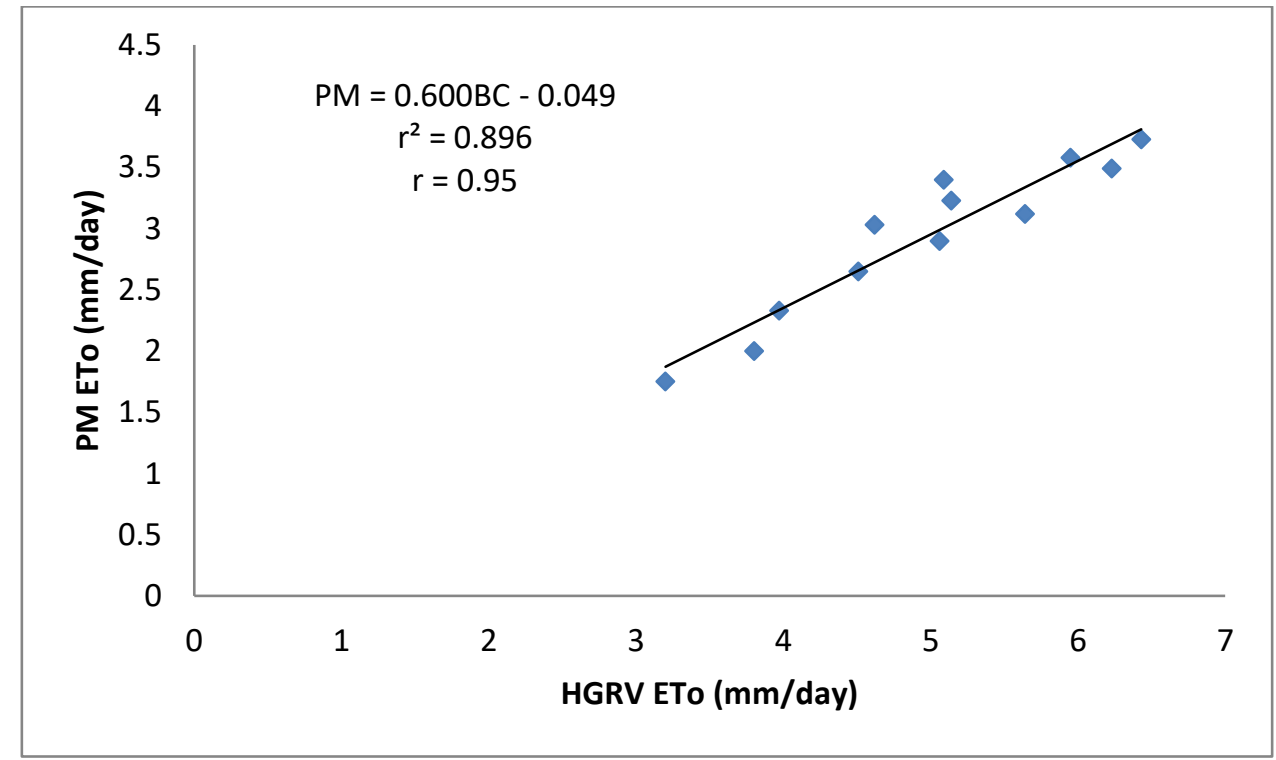

Fig. 5: Correlation between estimated ETo by PM and HGR

Correlation analyses between $\mathrm{PM}-\mathrm{ET}_{0}$ and each of $\mathrm{BC}$ $\mathrm{ET}_{0}$, HGRV-ETo and PiEv-ETo (Figures 4-6) are expressed in linear forms $(y=A x+B)$ and gave coefficients of determination, $r^{2}$ of $0.878,0.896$ and 0.835 , respectively. Hence, the correlation coefficients, $r$ are $0.94,0.95$ and 0.91 , for BC, HGRV and PiEv, respectively.
The results of concordance (d), correlation ( $r$ ) and confidence (c) tests for the different methods with respect to Penman-Monteith as standard, within Kaduna Central District, are presented in Table 2. The inference from the study is based on the confidence index. It shows that $\mathrm{BC}(\mathrm{C}=0.88,>85)$ has an excellent performance in relation to PM in the study area. 


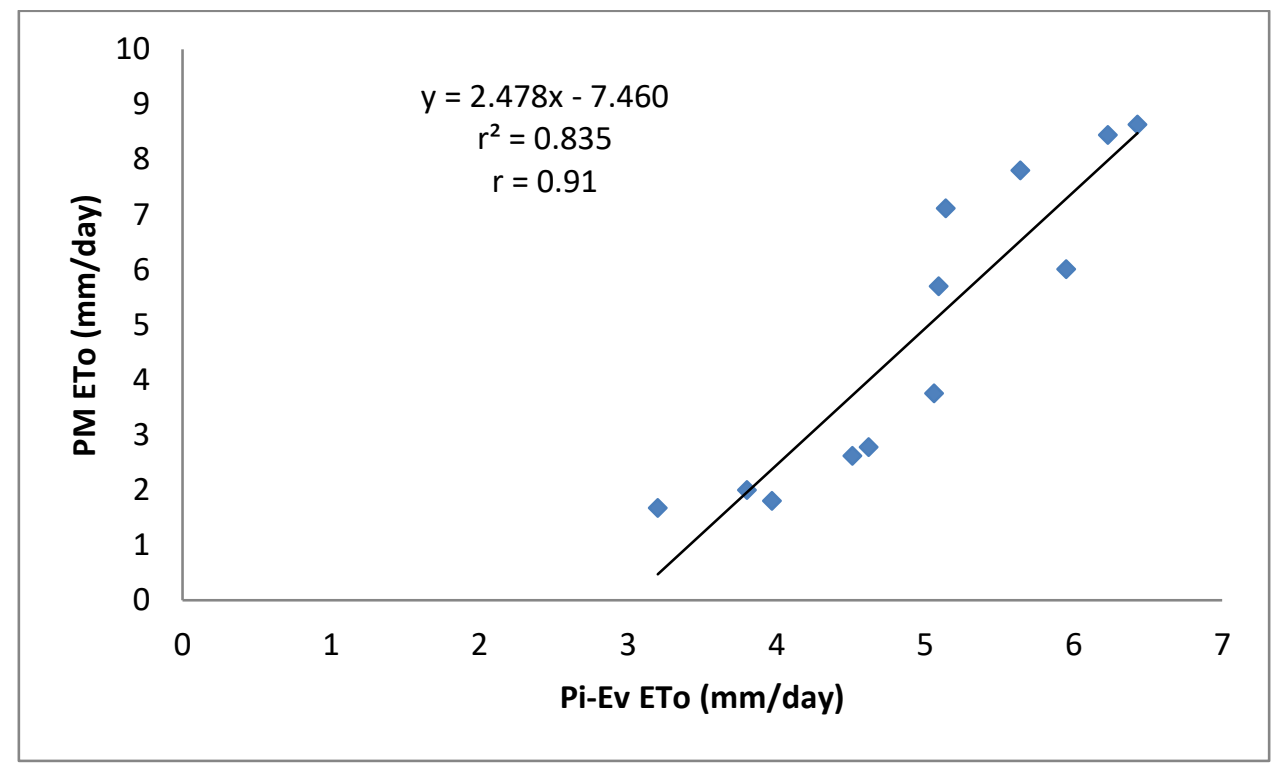

Fig. 6: Correlation between estimated ETo by PM and PiEv

The PM-PiEv relationship was just good (c $=0.67$ ) while that of PM-HGRV was poor. In a similar study in Cerrado environment, Brazil, the $\mathrm{BC}$ method presented the best performance as compared to solar radiation and the Ivanov methods [29]. Hence, this study has shown that Blaney Criddle method for ETo estimation will prove excellent in Kaduna Central District as an alternative to Penman Monteith if input parameters such as wind speed, relative humidity and solar radiation are not available; temperature data are the major data requirements.

\section{CONCLUSION}

Reference evapotranspiration rates were estimated within Kaduna Central District, Nigeria, given mean monthly climatic variables of thirty years (1986-2015) from three locations within the district, using four estimation methods which are: Penman-Monteith, Blaney Criddle, Hargreaves and Piche evaporimeter (atmometer). ETo obtained from Penman-Monteith were used as the standard upon which the other three were evaluated and compared. The highest ETo occurred in February, with the values of $6.38 \mathrm{~mm} /$ day, $6.25 \mathrm{~mm} /$ day and $8.6 \mathrm{~mm} /$ day for Penman-Monteith, Blaney Criddle and Piche evaporimeter methods, respectively. Hargreaves estimate was the variant, its highest occurring in March. In all the methods, the lowest ETo values were obtained in August.

Blaney Criddle method gave the closest relationship with Penman-Monteith method based on statistical analysis by means of confidence index. Hence, Blaney Criddle method can be used for irrigation scheduling within Kaduna Central District, Nigeria with the availability of monthly temperature data only, if there are not adequate data needed for Penman-Monteith estimation. A major limitation of this study is the unavailability of the needed data from other districts so as to have a broadened data base for making decisions on irrigation schedules in the region.

\section{REFERENCES}

[1]. UNL-IANR (2019) Crop Water Use (Evapotranspiration), Nebraska Agricultural ManagementNetwork(https://water.unl.edu/arti cle/agricultural-irrigation/crop-water-useevapotranspiration)

[2]. Allen R.G., L.S. Pereira, D. Raes, and M. Smith. Crop evapotranspiration: Guidelines for computing crop water requirements. Irrigation and Drainage Paper No. 56. 300 p. FAO Rome, Italy, 1998.

[3]. Isikwue, B.C., M.O. Audu and E.J. Ewe. Correlation of evapotranspiration with climatic parameters in some selected cities in Nigeria. Journal of Earth Sciences and Geotechnical Engineering, 5(4): 103-115, 2015

[4]. Hafeez M. and Akhtar A.K.. Assessment of Hargreaves and Blaney-Criddle methods to estimate reference evapotranspiration under coastal conditions, American Journal of Science, Engineering and Technology. Vol. 3. No. 4, 2018, pp 65-72, 2018

[5]. Abarikwu O.I., J.C. Adama and E.U. Ezeani. Relationship between reference evapotranspiration and some climatic parameters, Umudike, Nigeria. Agricultural Engineering International: CIGR Journal, 21(1); 28-33, 2019 
[6]. Razei T. and Pereira L.S. Estimation of ETo with Hargreaves-Samani and FAO-PM temperature methods for a wider range of climates in Iran. Agric. Water Management, 121: 1-18, 2013

[7]. Willmot C.J., Ackleson S.G., Davis R.E., Feddema J.J., Klink K.M., Legates D.R. and Rowe C.M. Statistics for the evaluation and comparison of models. Journal of Geoph. R., 90: 8995-9005, 1985

[8]. Blaney H.F. and Criddle W.D. Determining water requirements in irrigated areas from climatological and irrigation data. Washington, United States Department of Agric., Soil Conservation Service, 1950

[9]. Hargreaves G.H. and Samani Z.A. Reference crop evapotranspiration from temperature. Applied Engineering Agric., 1: 96-99, 1985

[10]. Daily Trust Newspaper. Dams boost irrigation farming in Kaduna. Thursday, 26 $6^{\text {th }}$ March, 2015.

[11]. Ammani A. Costs and returns analysis of small scale irrigated crop production in Kaduna State, Nigeria. Scientia Agriculturae, 10(2): 64-69, 2015

[12]. Kaduna State Ministry of Agriculture. Assessment of dams, springs and runoff rivers in Kaduna State. Doc. No: MOA/ADM//S/11/VIII/823

[13]. Yunusa B.K., Yusuf S., Zaharadeen I. and Abdulsalam A.F. Characteristics of rainfall variations in Kaduna State, Nigeria. Asian Journal of Advances in Agricultural Research, 4(3): 1-11, 2017

[14]. Onwuegbunam N.E., Onwuegbunam D.O. and Dare A. An analysis of rainfall in Kaduna Nigeria: Implication on irrigated agriculture. Book of readings: $8^{\text {th }}$ National Water Conference, Abeokuta, Nigeria. Pp. 180-185, 2018

[15]. NIMET. Climate of Kaduna, Nigeria, 1986 2015, Nigerian Meteorological Agency, 2015

[16]. KSWB. Weather data for Kaduna North and South (1986-2015), Kaduna State Water Board, 2015

[17]. Barbour K.M., Oguntoyibo J.S., Onyemelukwe J.O.C. and Nwafor J.C. (2002). Nigeria in Maps. Hodder and Stoughton Publishers, London, p. 24

[18]. Brouwer C. and M. Heibloem (1986). Irrigation water needs: Irrigation water management training manual No. 3, Food and Agriculture Organization, Rome, Italy.

[19]. Shahidian S., Serralheiro R., Serrano J., Teixeira J., Hale N. and Santos F. (2012). Hargreaves and other reduced-set methods for calculating evapotranspiration. In: EvapotranspirationRemote Sensing and Modeling. A. Irmark (Ed.) In Tech. 4:59-80

[20]. Hargreaves G.H. (1989). Accuracy of estimated reference evapotranspiration. Journal of Irrigation and Drainage Engineering, 115(6): 1000-1007

[21]. Hargreaves G.H. (1994). Defining and using reference evapotranspiration, Journal of Irrigation and Drainage Engneering, 120(6): 1132-1139

[22]. Bouchet R.J. Evapotranspiration reele, evapotranspiration potentielle, et production agricole. Ann. Agron. 14:743-824, 1963.

[23]. Casanova M.P., Messing I., Joel A. and Canete A.M. Methods to estimate lettuce evapotranspiration in greenhouse conditions in the central zone of Chile, Chilean J. Agric. Res. 69(1): 60-70, 2008

[24]. Willmott C.J. Some comments on the evaluation of model performance. Bullet of the American Meteorological Society, 63: 1309-1313, 1982

[25]. Camargo A.D. and Sentelhas P.C. Evaluation of the performance of different methods of estimation of potential evapotranspiration in the State of Sao Paulo Brazil. Rev Bras de Agrom, 5: 89-97, 1997.

[26]. OCDE. Water: fit to finance? Catalyzing national growth through investment in water security. Organization for Economic Cooperation and Development, Marseille, 2015.

[27]. Igbadun H.E., Ramalan A.A. and Oiganji E. (2012). Effects of regulated deficit irrigation and mulch on yield, water use and crop water productivity of onions in Samaru, Nigeria. Agricultural Water Management, 109 (2012): 162-169.

[28]. Igbadun H.E. and Oiganji E. (2012). Crop coefficients and yield response of onion under deficit irrigation and mulch practices in Samaru, Nigeria. African Journal of Agricultural Research, Vol. 7(36); 5137 - 5152).

[29]. Biesdorf E.M., Maciel E.B., Teixeira M.F.F., Teixeira J.S., Salla P.H.H., Pimentel L.D. and Imbuzeiro H.M.A. Comparison of reference evapotranspiration estimates obtained by different methods in relation to the PenmanMonteith method in Cerrado environment, Brazil. Journal of Experimental Agriculture International, 17(1) 1-9, 2017 